\title{
EVALUATION OF THE HEATING OF BROILERS IN SHED BY MEANS OF GAS HOODS AND UNDERFLOOR HEATING
}

\section{FLÁVIA F. DE LEVA ${ }^{1}$, JOSÉ R. CAMACHO ${ }^{2}$, DELLY OLIVEIRA FILHO ${ }^{3}$}

\begin{abstract}
This study was conducted to evaluate and compare the behavior of the heating inside poultry shed through gas hood and underfloor heating. The experiment was conducted in poultry shed belonging to the Federal Institute of Education, Science and Technology of Triângulo Mineiro Region, Uberlândia city - state of Minas Gerais (MG), Brazil. The dimensions of the shed are 24 meters long and 9.6 meters wide and with a ceiling height of 3.2 meters. The temperature was measured with an optical thermometer of Minipa brand, MT 350 model. It was used, to the analysis of temperature behavior, the public domain software FEMM 4.2, which uses finite elements techniques, with data collected from two lots. Underfloor heating is made using hot water flowing through a serpentine type system, which is installed below the bed; this hot water is from solar heaters. An energetic and economic assessment of the warming shed for raising chickens was realized. From the results obtained with the simulations, it may observe that the heating through the floor provides a more homogeneous distribution of temperature when compared with the hood heating. The flow of heat is upwards supplying, thus, the greatest need of heating of the bird, which is the pectoral part.
\end{abstract}

KEYWORDS: energy consumption, underfloor heating, environment, thermal comfort, solar energy

\section{AVALIAÇÃO DO AQUECIMENTO DE FRANGOS DE CORTE EM GALPÃO POR MEIO DE CAMPÂNULAS A GÁS E AQUECIMENTO DO PISO}

RESUMO: Essa pesquisa foi conduzida com o objetivo de avaliar e comparar o comportamento do aquecimento dentro de galpão avícola por meio de campânula a gás e aquecimento pelo piso. $\mathrm{O}$ experimento foi realizado em galpão avícola pertencente ao Instituto Federal de Educação, Ciência e Tecnologia de Triângulo Mineiro, Uberlândia-MG. As dimensões do galpão são de 24 metros de comprimento por 9,6 metros de largura e com pé-direito de 3,2 metros. A temperatura foi medida com termômetro óptico da marca Minipa, modelo MT 350. Foi utilizado para a análise do comportamento da temperatura o programa de computador de domínio público FEMM 4.2, que utiliza técnicas de elementos finitos, com dados coletados em dois lotes. O aquecimento pelo piso se dá com a utilização de água quente, passando por um sistema tipo serpentina, que é instalada abaixo da cama, sendo essa água quente proveniente de aquecedor solar. Foi realizada uma avaliação energética e econômica do aquecimento de galpão para criação de frangos. A partir dos resultados obtidos com as simulações, nota-se que o aquecimento através do piso fornece uma distribuição mais homogênea da temperatura quando comparado com o aquecimento tipo campânula. O fluxo de calor dá-se de baixo para cima, suprindo assim a necessidade maior de aquecimento da ave, que é na parte peitoral.

PALAVRAS-CHAVE: consumo energético, aquecimento pelo piso, ambiência, conforto térmico, energia solar.

\footnotetext{
${ }^{1}$ Dra., Federal Institute of Education, Science and Technology of Triangulo Mineiro - Campus Ituiutaba. 38.305-200; Ituiutaba-MG, Brazil; flavialeva@iftm.edu.br.

${ }^{2} \mathrm{PhD}$, Universidade Federal de Uberlândia, School of Electrical Engineering, Center for Research and Extension in Alternative Energy, 38400.902 - Uberlândia - MG, Brazil; jrcamacho@ufu.br.

${ }^{3}$ Professor Associado, Agricultural Engineering Department, Universidade Federal de Viçosa, Viçosa-MG, Brazil, delly@ufv.br. Recebido pelo Conselho Editorial em: 8-9-2010
}

Aprovado pelo Conselho Editorial em: 7-3-2013 


\section{INTRODUCTION}

Despite the international crisis, the world produced more chicken in 2010. The Brazilian Poultry Union (UBA), in its report 2010/2011, highlights that the world poultry industry produced 75.991 million tons in the period. First was the USA with 16.563 million tons of chicken in 2010, followed by China, with a production of 12.55 million tons. Brazil ranked third, with a production of 12.23 million tons of chicken meat; from the total volume of chickens produced by the country, $69 \%$ was destined for domestic consumption, and 31\% for exportation.

The trend of studies in agricultural project area is focused on technical and economic evaluation of technologies that aim for increasing efficiency, since the globalization of the economy requires that the agricultural sector is more productive and more profitable at the same time.

The evaluation of the environment of livestock may be performed under different approaches, such as air quality available nearby animals and thermal comfort. This is accomplished through the evaluation of pollutants that may be inhaled and possibly cause damage to human and animal health (NÂÃS et al., 2004), as the ammonia from the excreta of birds.

Inadequate air changes increase concentrations of particles of carbon monoxide (CO), carbon dioxide $\left(\mathrm{CO}_{2}\right)$ and ammonia $\left(\mathrm{NH}_{3}\right)$ within the facilities, decreasing concentrations of oxygen $\left(\mathrm{O}_{2}\right)$, thereby increasing the incidence of ascites in broilers (OWADA et al., 2007).

In cold periods, it is necessary to prevent loss of heat out of the aviary; therefore, the control of the openings is of fundamental importance. On the other hand, the ventilation features relevant function, primarily for hygienic reasons, making the air renewal in order to avoid undesirable gas concentrations inside the aviary (TINÔCO, 2001; NÂÃS et al., 2007; VIGODERIS et al., 2010).

Among the environmental factors, the thermal are the ones that most directly affect the bird, because compromise its more significant vital function, which is maintaining its homeothermy, and in the early stages of life, the supply of heat to the birds is essential when there is risk of cold stress (TINÔCO, 2001; MENEGALI et al., 2009).

Various types of poultry heaters have been developed, seeking the best way to provide heat and thermal comfort with lower energy consumption. According to COBB (2008), in the choice of the heating system, we should not take into account only the cost, but the ability to heat production and the consequences that this system will bring to the air quality and poultry litter.

Gas heaters are quite functional due to its resistance, low maintenance and mobility, and they may be reinstalled easily and quickly (CRIAÇÃO DE ANIMAIS, 2008; FUNCK, 2006). The underfloor heaters, on the other hand, are rarely used. There are studies in the area using electrical resistance, while there is not an extensive research for the ones using hot water.

The underfloor heating by electric resistance, according to WICKLEN \& CZARICK (1988), may be used to adjust the moisture content of the bed, which can reduce the production of ammonia. According to ABREU (1994), it was observed that temperature values above $35^{\circ} \mathrm{C}$ on the upper surface of the bed layer on the floor-heating systems may toast the bed. According to ROSSI et al. (2002), this heating system shows excellent results, for it can keep the temperature on the ground very close to the set temperature and it shows reliability.

It is believed that the reasons for the lower use of facilities with underfloor heating are purely economic and of difficult installation, when compared to using the gas hoods. On the other hand operating costs, especially energy, may be very low with underfloor heating systems.

The underfloor heating system, also called radiant heating, is an important alternative for obtaining thermal comfort and, despite its simplicity, implies care in design, such as the choice of heat source, control strategy, selection of materials and constructive details.

According to BOKZIR \& CANBAZOGLU (2004), the underfloor heating is a type of internal heat source mainly characterized by uniformity of temperature distribution and efficiency in 
obtaining a favorable thermal sensation. The understanding of the underfloor heating concept is of fundamental importance. It may be implemented based on simplified models of thermal performance with the use of solar water heaters.

However, projects of heating of poultry houses involve several variables. So that using behavioral analysis software emerges as important options for a more accurate and timely evaluation, consistent with the local reality and especially reducing costs.

There is the need for studies to prove the economic viability of new technologies that may influence on the physical production as well as on cost reduction and/or energy consumption. It is noteworthy that the reduction in consumption without sacrificing production is one of the main challenges of the Brazilian poultry (BUENO, 2004).

As a first step, we sought to locate, in the world market and in the scientific literature, aid programs in the investigation of the temperature behavior and the use of alternative energy sources that could replace and/or reduce the use of conventional forms of heating in poultry houses (NOGUEIRA \& ZÜRN, 2005). The objective of this study was to evaluate and compare the behavior of the heating within poultry shed by gas hoods and underfloor heating.

\section{MATERAL AND METHODS}

Data collection was carried out in the poultry shed belonging to the Federal Institute of Education, Science and Technology of Triângulo Mineiro Region, Uberlândia Campus (formerly Federal Agricultural School of Uberlândia), better known as the Agricultural College, in Uberlândia, Triângulo Mineiro region, distant $25 \mathrm{~km}$ from the city center, in the period between October 19th, 2007, and August 20th, 2008. The head office of the School is located in the geographical coordinates $18^{\circ} 46^{\prime} 12^{\prime}$ South latitude and 48 $17^{\prime} 17^{\prime \prime}$ West longitude.

It was conducted the data collection for this article in the same installation, in two lots. The dimensions of the sheds are $24 \times 9.6 \mathrm{~m}$, ceiling height of $3.2 \mathrm{~m}$, short wall of $0.6 \mathrm{~m}$, and ridge vent of $1.5 \mathrm{~m}$ wide and $0.5 \mathrm{~m}$ high.

The facility is equipped with gas heating system, consisting of three hoods, placed at $1.1 \mathrm{~m}$ above the floor and positioned to give uniformity in the chicks heating. The bed used is rice straw and has a thickness of $8 \mathrm{~cm}$.

In this shed, Figure 1(a), it occurs the poultry breeding in an educational nature, i.e., for the teaching of technical course in poultry. It is normally installed a total of 2,000 birds per lot, in an initial space of $15 \%$ of the shed, where the protective circles are installed, which are made by Eucatex sheets, as shown in Figure 1(b). The protective circles are used as a security measure, so that the chicks do not agglomerate into a corner, which can cause death by trampling and suffocation; the protective circles are also used to facilitate a uniform distribution of heat to the level of the birds and to avoid air drafts in their direction, as well as to facilitate management.

As the first few weeks are of prime importance, it is necessary to maintain the proper temperature for the thermal comfort of the bird. According to FERREIRA (2005), this temperature should be in the range between $32^{\circ} \mathrm{C}(305.15 \mathrm{~K})$ and $35^{\circ} \mathrm{C}(308.15 \mathrm{~K})$ in the first week, and between $28^{\circ} \mathrm{C}(301.15 \mathrm{~K})$ and $32^{\circ} \mathrm{C}(305.15 \mathrm{~K})$ in the second week.

The experimental data collected comprised two lots of creation, measured with optical thermometers of Minipa brand, MT 350 model. These data are based on the verification of the value of the temperature at various locations around the shed and at various times of day, temperature measurements were carried out in the hoods, the internal environment, the short wall, the floor, the bed, the ceiling and the ridge vent; outside, the temperature was measured on the sidewalk, the canvas, on the canvas of the short wall, and the roof. The measurement interval was one hour. 
These values are used in the FEMM program in two specific situations, the first one considering the local situation - i.e., with the use of gas hoods (LPG) -, and the other one considering the proposed type of heating - which is the underfloor heating with the use of coils.

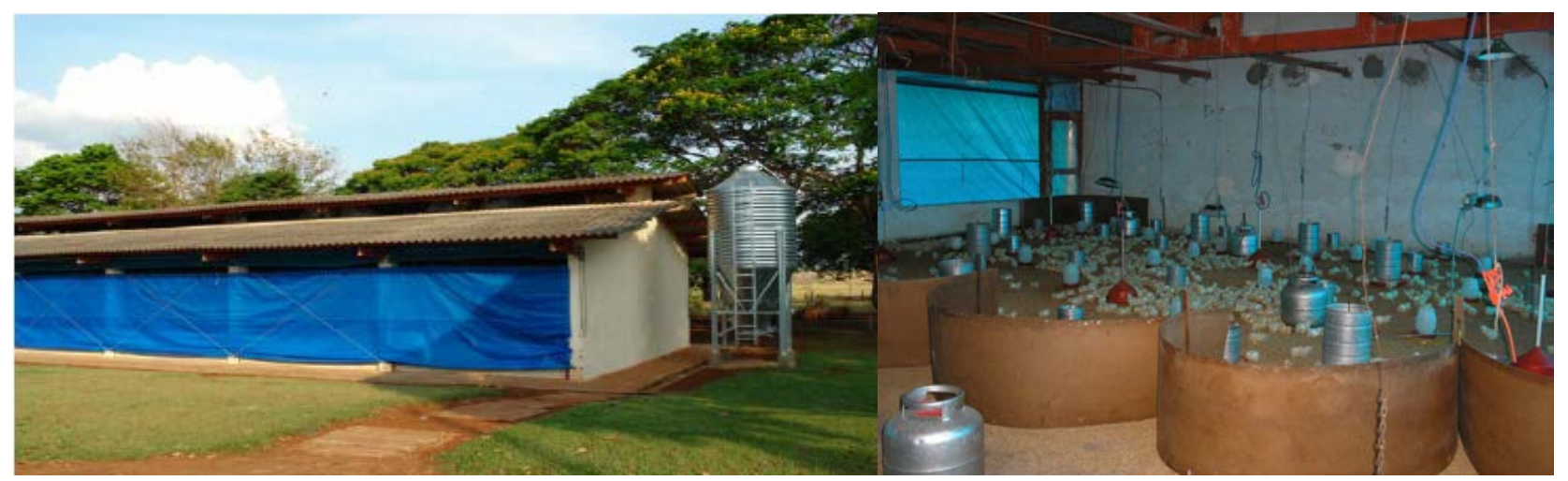

(a)

(b)

FIGURE 1. (a) Lateral view of the poultry shed, (b) Inside view the poultry shed with the circles for the birds' containment.

\section{a) Heating sources}

It was performed an analysis of the temperature behavior of artificial heating inside sheds of broiler breeding. The following methods of heating were used:

Gas hoods: where the poultry heating is performed with the heat flow downward from the heat source to the birds;

Underfloor heating through the use of hot water pipes, buried in the ground.

The use of underfloor heating system in poultry sheds, Figure 2, which consists of using a panel (solar heating) to heat the water and store it in a boiler (hot water tank). The hot water circulates through the coil; this coil may be located recessed in the floor, which would be ideal for new or existent sheds, and it may also be located on the floor and below the bed, forming an upwards heating system.

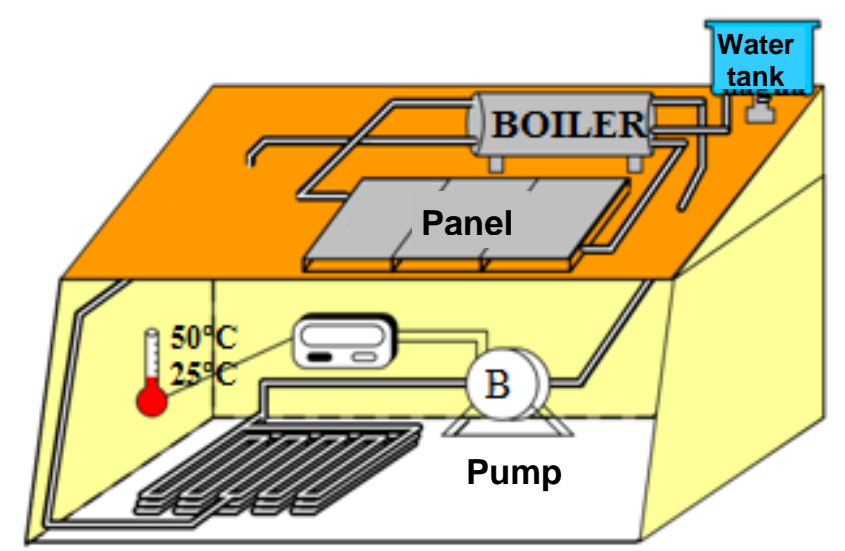

FIGURE 2. Suggestion of installation of the underfloor heating system.

The radiant heating system through hot water circulation under the floor has as the main advantage the possibility of being held by several sources of energy, such as gas, electricity and solar energy. Thus, it may use, to heat the water, the shed bed itself for production of gas (biogas) and which may later be used to heat the water.

Biogas production occurs through biodigestors, most common being the use of anaerobic digestion process of the bed, which may return to the system $46.7 \%$ of the amount of energy 
exiting, enabling the reduction of poultry heating costs, as the biogas produced may replace the LPG, besides the additional benefits credited to environmental economics (SANTOS \& JUNIOR, 2004).

The cross-linked polyethylene (PEX) has established itself as the most durable material for pipes installed in the subfloor, where hot water circulates. In addition to PEX, other material that may be used is copper.

This radiant system includes two heat exchangers: between the heat source and water, whose water is stored between the water and the environment. Important design parameters are the diameter of the pipes, the distance between these pipes and the distribution piping in the floor (OLESEN, 2004).

\section{b) Simulation}

The analysis of the temperature behavior inside the poultry sheds is held in the public domain software FEMM 4.2 (Steady-State Finite Element Heat Conduction Solver), which makes finite element analysis. The FEMM program solves problems in plain and asymmetric two-dimensional domains.

The FEMM program brings in its results the temperature unit in Kelvin. As for the comparative graphs of temperature in certain positions, they are performed with MATLAB program, and the unit is converted to ${ }^{\circ} \mathrm{C}$. Although the SI unit for temperature is Kelvin (K), the use of Celsius scale is still quite common. The zero on the Celsius scale $\left(0^{\circ} \mathrm{C}\right)$ is equivalent to $273.15 \mathrm{~K}$.

In the geometric structure, it is where it is defined the material properties and boundary conditions, and also the definition of materials which will be used to the shed model. This boundary condition can be represented mathematically as:

$$
\mathrm{k} \frac{\partial \mathrm{T}}{\partial \mathrm{n}}+\mathrm{f}=0
$$

In which:

$\mathrm{n}$ - represents the direction of the normal to the boundary;

$\mathrm{k}$ - thermal conductivity $\left(\mathrm{W} \mathrm{m} \mathrm{m}^{-1} \mathrm{~K}^{-1}\right.$;

T- temperature $(\mathrm{K})$;

f- heat flow $\left(\mathrm{W} \mathrm{m}^{-1}\right)$.

In convection, this boundary condition can be represented as:

$$
\mathrm{k} \frac{\partial \mathrm{T}}{\partial \mathrm{n}}+\mathrm{h}\left(\mathrm{T}-\mathrm{T}_{0}\right)=0
$$

In which:

$\mathrm{k}$ - thermal conductivity $\left(\mathrm{W} \mathrm{m}^{-1} \mathrm{~K}^{-1}\right)$;

$\mathrm{T}$ - temperature $(\mathrm{K})$;

T0- initial temperature (K);

$\mathrm{h}$ - is the coefficient of heat transfer $\left(\mathrm{W} \mathrm{m}^{-1} \mathrm{~K}^{-1}\right)$.

In the radiation, the heat flow is described in the mathematical form as:

$$
\mathrm{k} \frac{\partial \mathrm{T}}{\partial \mathrm{n}}+\beta \mathrm{k}_{\mathrm{sb}}\left(\mathrm{T}^{4}-\mathrm{T}_{0}^{4}\right)=0
$$

In which:

$\mathrm{T}$ - temperature $(\mathrm{K})$;

$\mathrm{T}_{0}$ - initial temperature $(\mathrm{K})$;

$\beta$ - is the emissivity of the surface (a value between 0 and 1 );

$\mathrm{k}_{\mathrm{sb}}-$ is the Stefan-Boltzmann constant (with value of $5.67 \times 10-8 \mathrm{~W} \mathrm{~m}^{-2} \mathrm{~K}^{-4}$ ). 
The pre-processing is the part of design, geometric structure of the problem to be solved, where it is defined the properties, the boundary conditions and material to be analyzed. Identifying the factors that influence the problem in a relevant way, which involves the appropriate choice of physical principles and independent and dependent variables, resulting in a mathematical model consisted of a set of differential equations.

Processing, Figure 3(a), is a vital part of the solution of the Finite Element process, which is the triangulation process of the geometric structure defined in the preprocessing.

And the post-processing, Figure 3(b), is the process where the resolution of the differential equations occurs in order to obtain temperature values in the solution domain.

The simulation of the temperature behavior occurred in cross-section (width) of the shed at a distance of $1.9 \mathrm{~m}$ from the edge, in the position of the hoods, and in the first week, the fence is at a distance of $3.6 \mathrm{~m}$ from the wall.

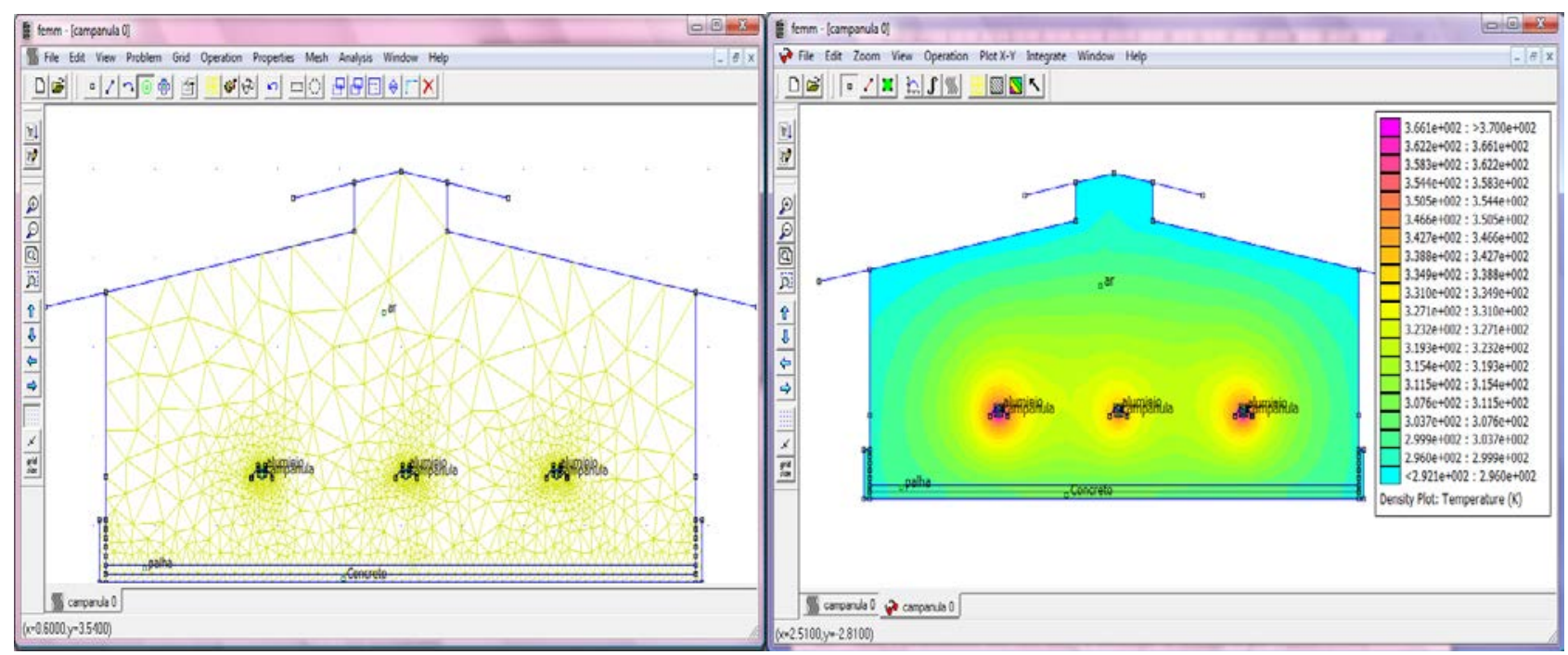

(a)

(b)

FIGURE 3. FEMM simulation (a) processing and (b) post-processing.

The first lot in analysis was received on October 19th and removed on December 5th, 2007, and the second one was received on July 11th and removed on August 20th, 2008. The graphs plotted consider as axes the relevant positions to the birds size and type of heating, such as in bed height, from 0.1 to $0.2 \mathrm{~m}$ of it, the height of the short wall $(0.6 \mathrm{~m})$, and ceiling height $(3.2 \mathrm{~m})$.

An analysis was made, to the Agricultural College, of the temperature behavior with the proposed heating, through coil, in which circulates the hot water.

\section{c) Economic analysis}

Another aspect addressed in this article is to verify the amount of energy that the LPG supplied for heating to occur during the first weeks of the bird lives. For this analysis, it was used the data collected relating to lots 1 and 2.

For the calculation in watts, it was use Equation 4.

$$
P=\frac{m c\left(T_{2}-T_{1}\right)}{860 h}
$$

In which:

$\mathrm{P}=$ Power $(\mathrm{kW})$

$\mathrm{m}=$ mass of the substance to be heated $(\mathrm{kg})$

$\mathrm{c}=$ specific heat of the substance $\left(\mathrm{kcal} / \mathrm{kg} .{ }^{\circ} \mathrm{C}\right)$

$\mathrm{T}_{1}=$ initial temperature $\left({ }^{\circ} \mathrm{C}\right)$ 
$\mathrm{T}_{2}=$ final temperature $\left({ }^{\circ} \mathrm{C}\right)$

$\mathrm{h}=$ desired heating time in hours $(\mathrm{h})$

$860=$ constant

\section{RESULTS AND DISCUSSION}

Figure 4 shows the simulation result of the temperature behavior in cross-section (width) of the shed of the Agricultural College on October 20th, 2007, part of lot 1, being measured at 07:30am. The temperature outside the shed (ambient) of $19^{\circ} \mathrm{C}$ and the temperature at the height of the base of the hood in the value of 101,108 and $102^{\circ} \mathrm{C}$ for hoods from left to right.

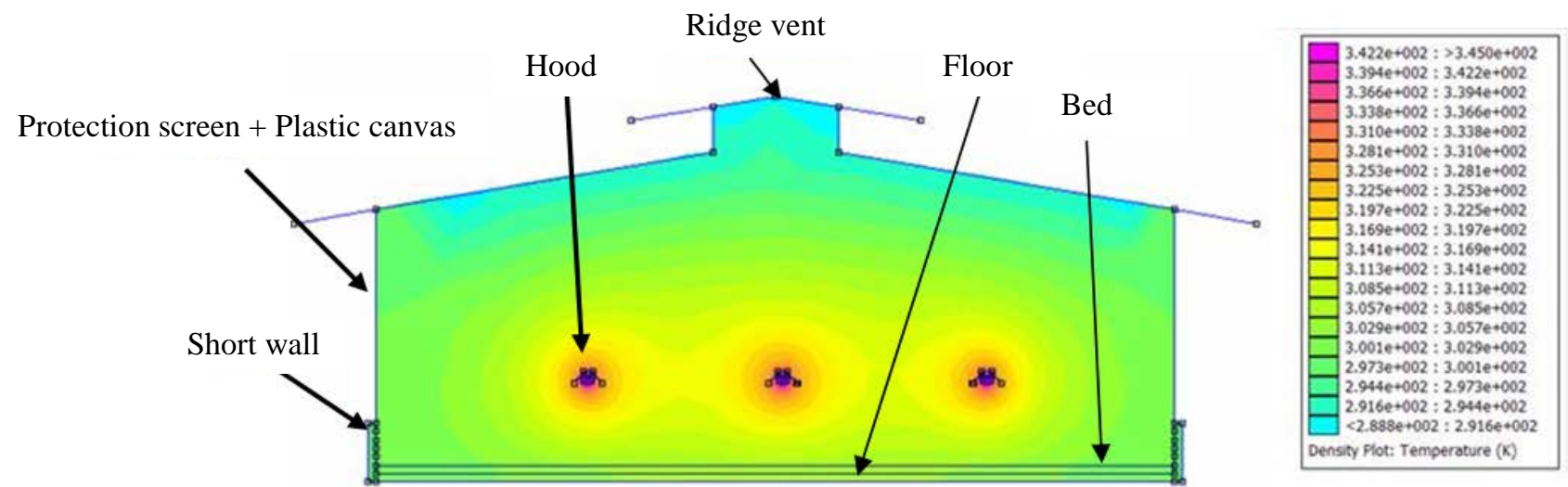

FIGURE 4. Temperature behavior at the shed using data measured in October 20th, 2007, transversal cut.

Figure 5 represents the temperature at specific heights: at the height of the bed, at $0.1 \mathrm{~m}$ of the bed, at $0.2 \mathrm{~m}$ of the bed, and at the height of the short wall. Which could be observed for the same alignment, for example, in the height of the bed there is a small variation in the temperature value, and as they approach the heat source, this variation becomes greater, contrasting that there is a range of action for the hood.

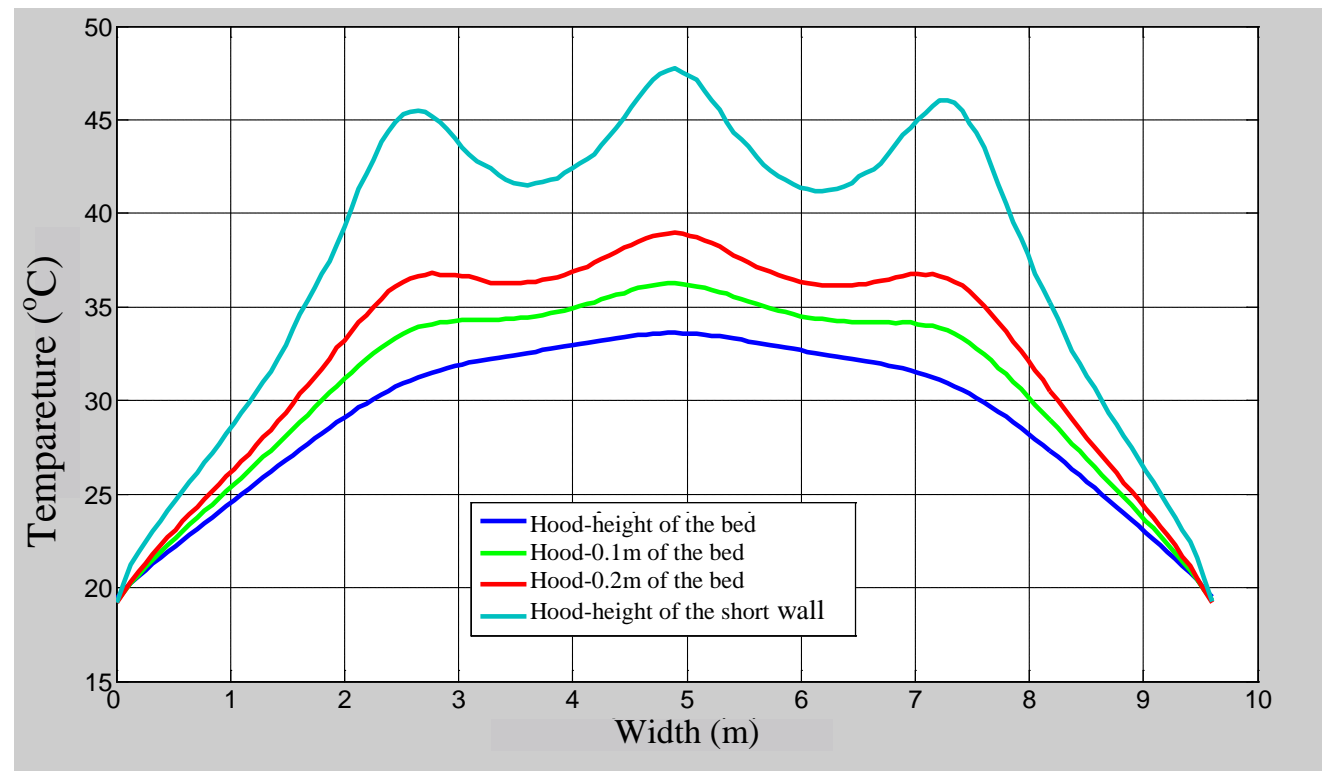

FIGURE 5. Profile of temperature inside the shed using hood heating, measured value, October 20th, 2007, at 7:30am.

It can be seen that in the vicinity of the hood, which is the heat source, the temperature is higher and the distribution of this heat is not very homogeneous, so as to create a "operation field" for each hood. According to ABREU et al. (2000), the ideal temperature must be continuous at 
$35^{\circ} \mathrm{C}$ for the first week of bird's life. The temperature outside the shed also influences the temperature of the ends of the shed.

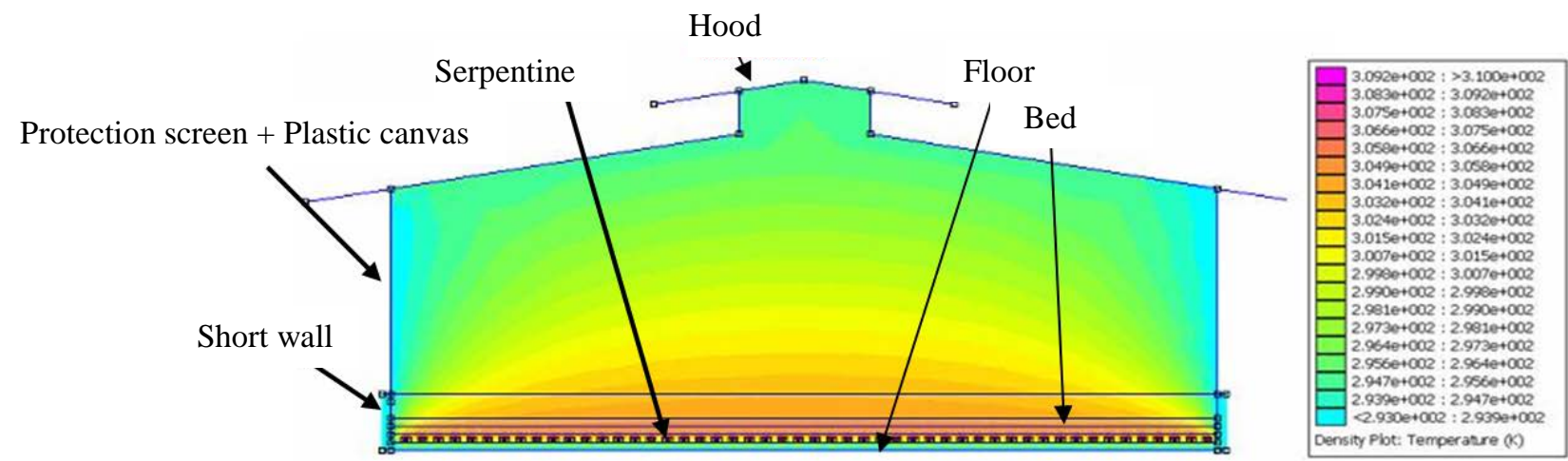

FIGURE 6. Temperature behavior considering heating by coil, based on data collected in October 20th, 2007, at 7:30am.

It is noted, through Figure 6, that in the vicinities of the coil, which is the heat source, the temperature is higher and this heat distribution is very homogeneous, the temperature outside the shed has less influence on the temperature of the ends of the shed when compared to the use of hoods.

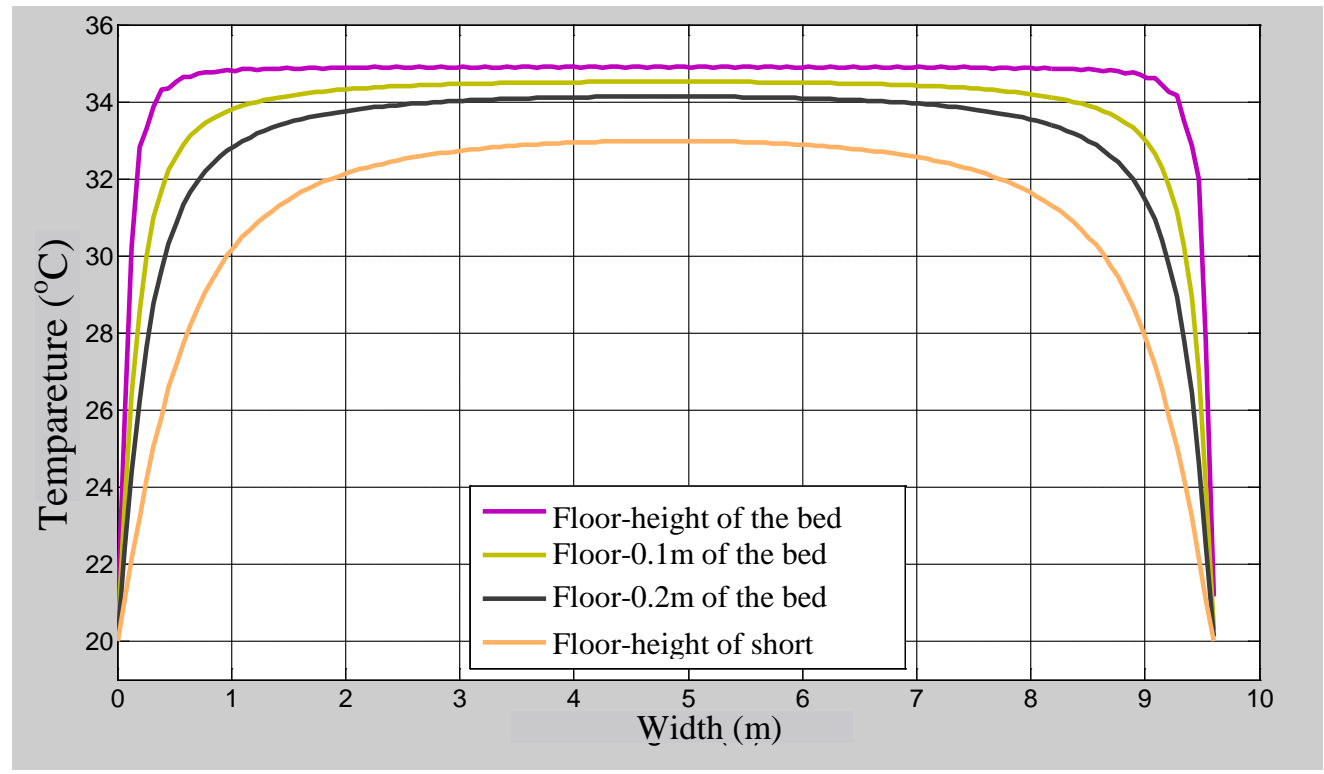

FIGURE 7. Profile of temperature inside the shed using underfloor heating, value simulated, October 20th, 2007, at 7:30am.

Figure 7 represents the temperature profile inside the shed with the use of the underfloor heating, at specific heights: at the height of the bed, at $0.1 \mathrm{~m}$ of the bed, at $0.2 \mathrm{~m}$ of the bed, and at the height of the short wall. The ambient temperature is $19^{\circ} \mathrm{C}$, on October 20th, 2007, at 7:30am.

Figure 8 represents the temperature value at specific locations: at the height of the bed, at $0.1 \mathrm{~m}$ of the bed, at $0.2 \mathrm{~m}$ of the bed, and at the height of the short wall. Where it can be observed that in one alignment. 


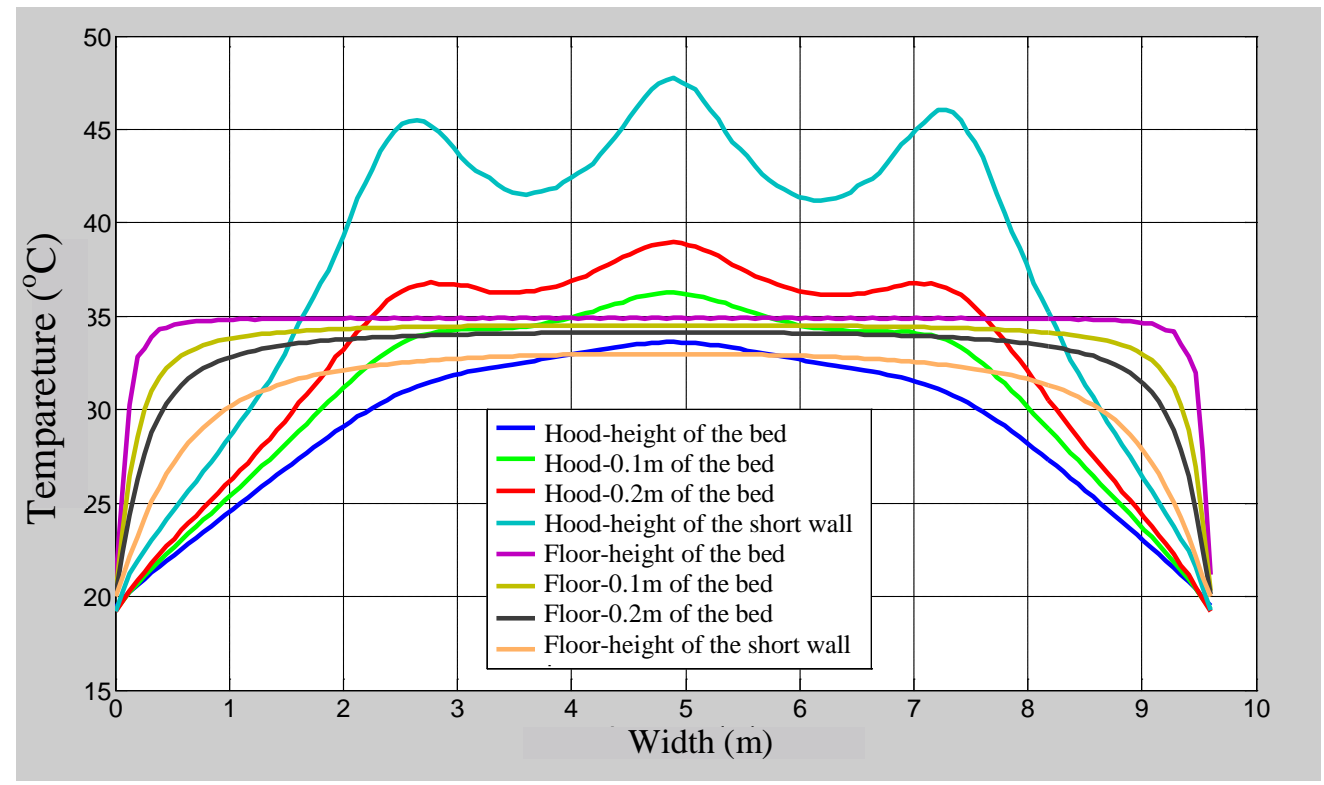

FIGURE 8. Comparison of the temperature profiles using hoods and underfloor heating within the shed on October 20th, 2007, at 7:30am.

Figure 9 represents the simulation results of the temperature behavior in cross-section (width) of the shed of the Agricultural College on October 20th, 2007; the temperature was measured at $11: 30 \mathrm{am}$, the temperature outside the shed (ambient) is $28^{\circ} \mathrm{C}$, and the temperature at the height of the base of the hood is 48,51 and $45^{\circ} \mathrm{C}$ for hoods from left to right. The temperature of the water flowing through the coil is $38^{\circ} \mathrm{C}$.

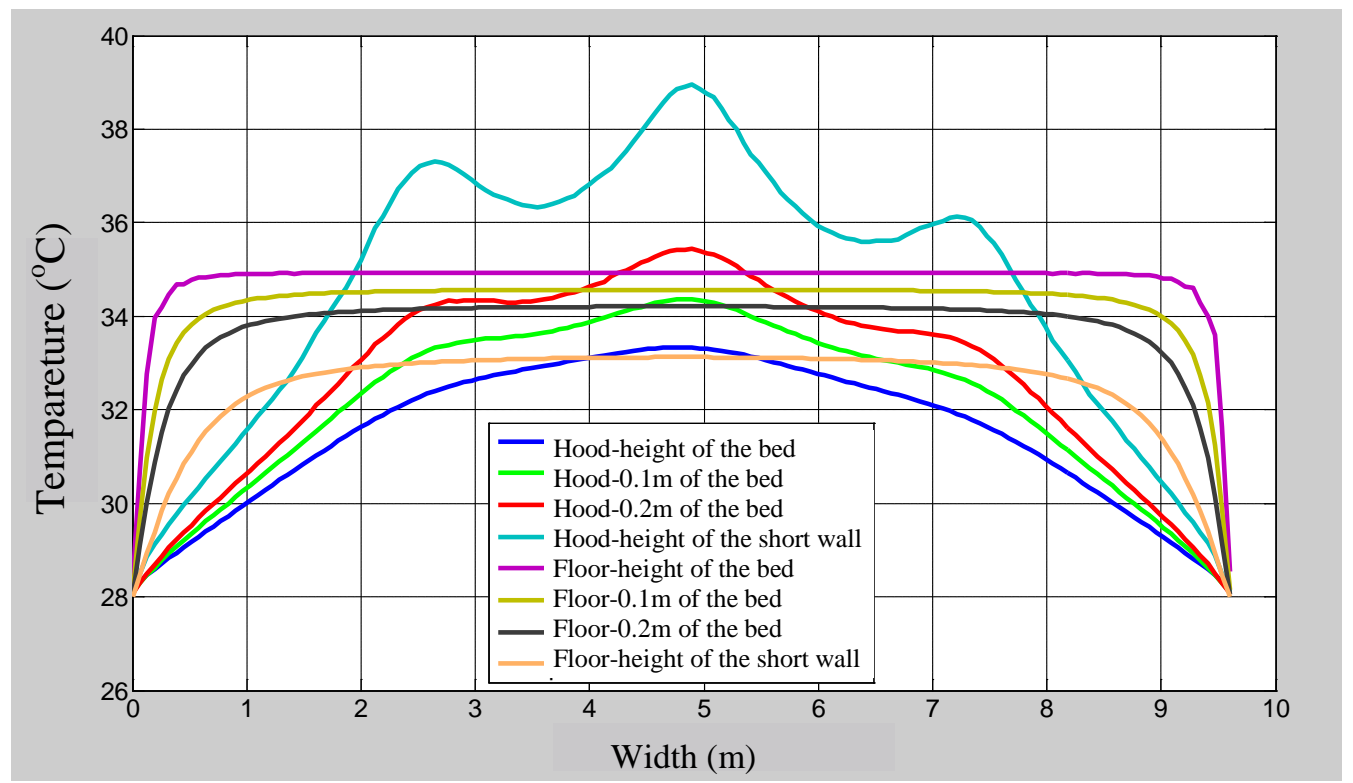

FIGURE 9. Comparison of the temperature profiles using hoods and underfloor heating within the shed on October 20th, 2007, at 11:30am.

Figure 10 represents the simulation results of the temperature behavior in cross-section (width) of the shed of the Agricultural College on July 12th, 2008, belonging to the lot 2; the temperature was measured at 08:00am, the temperature outside the shed (ambient) is $16^{\circ} \mathrm{C}$, and the temperature at the height of the base of the hood is 108,106 and $106^{\circ} \mathrm{C}$ for the hoods from left to right. The water temperature is $45^{\circ} \mathrm{C}$. 


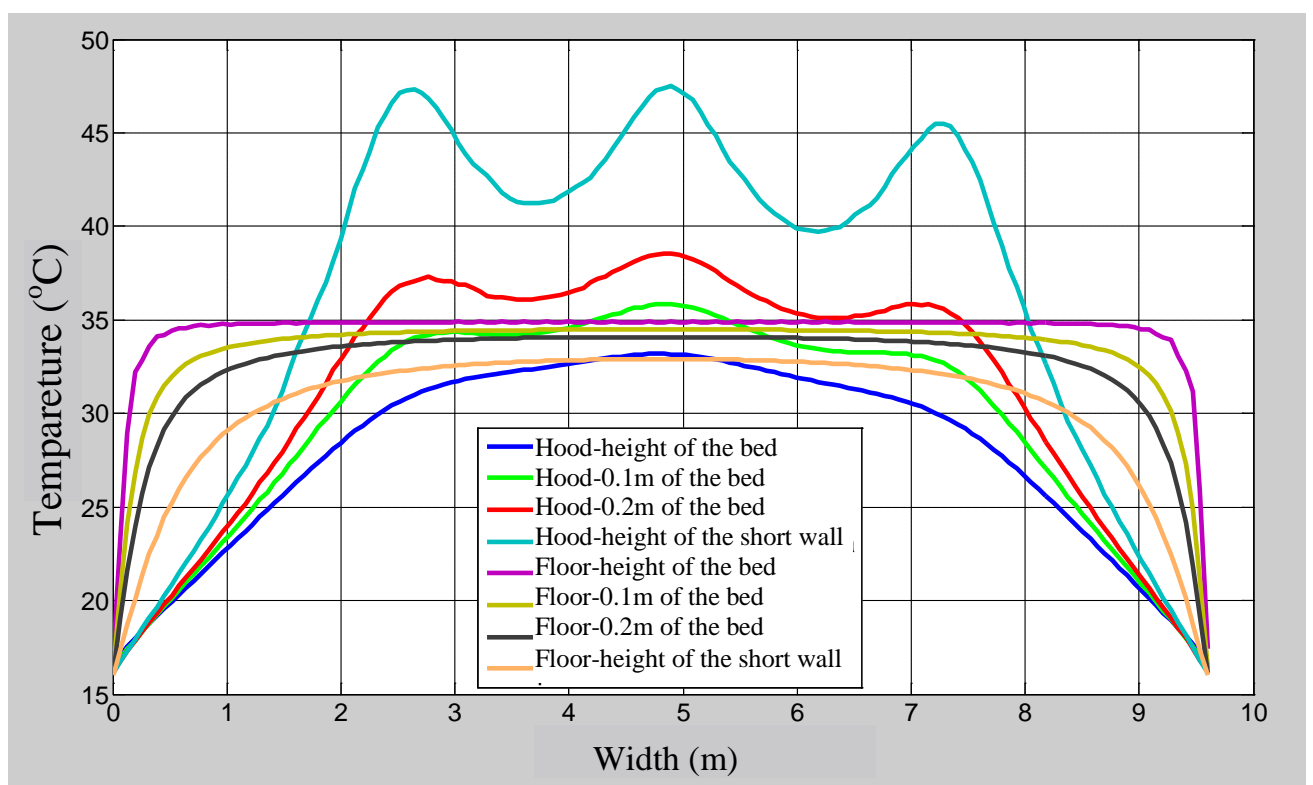

FIGURE 10. Comparison of the temperature profiles using hoods and underfloor heating within the shed on July 12th, 2008, at 8am.

Still for the lot 2, on July 12th, 2008, at 11:00am, the temperature outside the shed (ambient) is $22^{\circ} \mathrm{C}$, and the temperature at the height of the base of the hood is 78,79 and $74^{\circ} \mathrm{C}$ for the hoods from left to right. The water temperature is $40^{\circ} \mathrm{C}$.

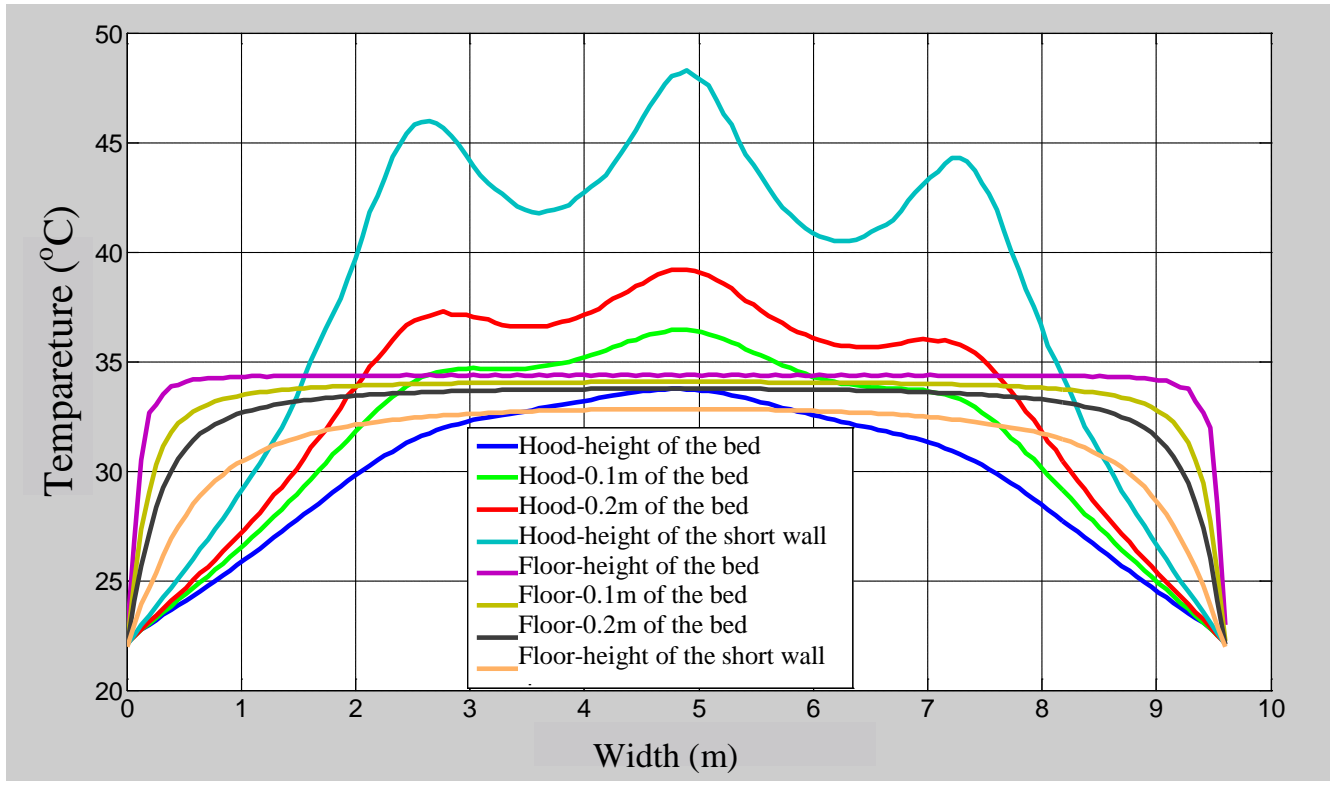

FIGURE 11. Comparison of the temperature profile using hoods and underfloor heating within the shed on July 12th, 2008, at 11am.

For example, in height of $0.1 \mathrm{~m}$ above the bed there is a greater uniformity of heat distribution; this is because the heat source is not as concentrated as in the hood, but it is distributed as homogeneously as possible within the area to be heated. This distribution assists for the temperature outside the shed to have not much influence on the ends of the shed.

According to BUSO (2005), the use of radiant heating provides a uniform temperature distribution, which enhances the feeling of thermal comfort. And according to FRÄNKISCHE (2009), the radiant floor system provides a better sensation of comfort and well-being, since the temperature distribution is uniform throughout the site. 
From the results obtained with the use of Finite Element Method for thermal analysis, one may note that the underfloor heating through coil, the proposed method, provides a more homogeneous heat distribution when compared to the use of hoods. Thus, it is possible to note that, in a same line, we hardly observe variation of the temperature value.

Making an economic analysis of heating for the Lot 1, where 120kg of LPG were consumed in a total of $262 \mathrm{~h}$, with the use of hoods for heating of 2,000 chicks, so that consumption was 9.23 cylinders of $13 \mathrm{~kg}$. We verify an equivalent expense, in terms of power, of $1,639.53 \mathrm{kWh}$, corresponding to R $\$ 396.93$ (cost of LPG cylinder in December, 2009, in the amount of R\$43.00).

Making analysis of equivalent cost in terms of power in $\mathrm{kW}$, for this first lot would be necessary $6.28 \mathrm{~kW}$ for a total of $262 \mathrm{~h}$ of consumption, which is equivalent to $1,639.53 \mathrm{kWh}$, as the amount charged by CEMIG in December, 2009, is 0.29036637, corresponding to R $\$ 481.47$.

For the heating of Lot 2, it was required $151 \mathrm{~kg}$ of LPG, in a total of $312 \mathrm{~h}$ and $30 \mathrm{~min}$, giving an equivalent cost in terms of power of a total of 2,062.66kWh. The average consumption of gas (LPG) used in hoods for heating of 2,000 chicks in the third lot in analysis was 11.62 cylinders of $13 \mathrm{~kg}$, which corresponds to R $\$ 499.66$ (cost of LPG cylinder in December, 2009, in the amount of $\mathrm{R} \$ 43.00)$.

Making analysis of equivalent cost in terms of power in $\mathrm{kW}$, for this another lot would take $6.28 \mathrm{~kW}$ for a total of $312 \mathrm{~h}$ and 30 minutes of consumption, which is equivalent to $1,962.5 \mathrm{kWh}$, as the amount charged by CEMIG in December, 2009, is 0.29036637 , corresponding to $\mathrm{R} \$ 576.31$. Using the proposed heating, we would not have spent, since the fuel is solar radiation.

The increase of moisture in the air due to a rainy season, besides the accumulation of moisture in the bed, provided by the excreta of birds, increasing the amount of gases such as ammonia, which in the winter can lead to the development of pathogens (NÃ̃̃S et al., 2007), which can be alleviated with the use of underfloor heating, because it makes the bed remain drier (ABREU \& ABREU, 2002).

In addition to the homogeneous distribution of heat, soften the amount of ammonia that is released by bird excreta, this kind of heat still stands out because it benefits the environment, provided by the use of solar water heaters, as renewable energy adds value to the final product, because it is less dependent on petroleum-based fuels.

\section{CONCLUSION}

Comparing the behavior of heating within poultry shed by means of the gas hood and the underfloor heating, it may observe that the proposed method, underfloor heating through coil, provides a more homogeneous heat distribution in the same height in the size of the shed. It is an excellent method for proper maintenance of the temperature for the birds. Despite the high initial investment, this type of heating is paid in a short interval of time, since the fuel is solar radiation.

\section{ACKNOWLEDGEMENTS}

To the Federal Institute of Education, Science and Technology of Triângulo Mineiro Region Uberlândia Campus (Agricultural College), for the opportunity to make the data collection. To CNPq and FAPEMIG for support.

\section{REFERENCES}

ABREU, P. G. Sistemas de aquecimento em piso, com resistência elétrica, para criação de aves. 1994. 82f. Dissertação (Mestrado em Engenharia Agrícola) - Universidade Federal de Viçosa, Viçosa, 1994.

ABREU, P. G.; ABREU, V. M. N. Caracterização dos sistemas de aquecimento para aves. Concórdia: Embrapa - CNPSA, 2002. 10p. 
ABREU, P. G.; ABREU, V. M. N.; BAÊTA, F. C. Metodologia de dimensionamento de sistemas de Aquecimento em Piso, em Função da Temperatura e Espessura de Cama, para Criação de Frangos de Corte. Revista Brasileira de Ciências Avícola, Campinas, v. 2, n. 1, Jan./Apr 2000.

BOZKIR, O.; CANBOZAGLU, S. Unsteady thermal performance analysis of a room with serial and parallel duct radiant floor heating system using hot airflow. Energy and Buildings. Elsevier, 2004. v. 36, p. 579-586.

BUENO, L. G. F. Avaliação da eficiência energética e do conforto térmico em instalações de frango de corte. Dissertação (Mestrado) - Universidade Estadual de Campinas, Faculdade de Engenharia Agrícola, Campinas, 2004.

BUSO, P. C. Manual de Condicionamento de Ar utilizando o Piso Elevado Monolítico Werden, 16p, 2005. Disponível em: <http://www.werden.com.br/index.asp>. Acesso em: 21 jun. 2010.

COBB. Broiler managent guide. 2008. Disponível em: <www.cobb-vantress.com>. Acesso em: 18 maio 2012.

CRIAÇÃO DE ANIMAIS: Instalações para frango de corte, 2008. Disponível em: <

http://criacaodeanimais.blogspot.com.br/2008/12/instalaes-para-frango-de-corte.html>. Acesso em: 18 maio 2012.

FERREIRA, R.A. Maior produção com melhor ambiente para aves, suínos e bovinos. Viçosa: Aprenda Fácil, 2005. 371p

FRÄNKISCHE. Manual de técnica para instalações domésticas. 2009. 12p.

FUNCK S. R. Avaliação Energética e Desempenho de Frango de Corte em uma Agroindústria Avícola com Sistema Automático de aquecimento a Gás e Lenha. 2006. 56f. Dissertação (Mestrado em Engenharia Agrícola) - Universidade Estadual do Paraná, Cascavel, 2006.

MENEGALI, I.; TINOCO, I. F. F.; BAÊTA, F da C.; CECON P. R.; GUIMARÃES, M. C. C.; Cordeiro M. B. Ambiente térmico e concentração de gases em instalações para frangos de corte no período de aquecimento. Engenharia Agrícola, Jaboticabal, v.13, n.2, p.984-990, 2009.

NÃÃS, I. A.; SOBESTIANSKY, J.; JÚNIOR, P. B. Manual de rastreabilidade na produção animal intensiva. Goiânia: Pfizer, 2004. 76 p.

NÃÃS, I. de A.; MIRAGLIOTTA, M. Y.; BARACHO, M. dos S.; MOURA, D. J. de. Ambiência aérea em alojamento de frangos de corte: poeira e gases. Engenharia Agrícola, Jaboticabal, v.27, n.2, p.326-335, 2007.

NOGUEIRA, C. E. C.; ZÜRN, H. H. Modelo otimizado para sistemas energéticos renováveis em ambientes rurais. Engenharia Agrícola, Jaboticabal, v.25, n.2, p.341-348, 2005.

OWADA, A. N.; NÃÃS, I. A.; MOURA, D. J.; BARACHO, M. S. Estimativa de bem-estar de frango de corte em função da concentração de amônia e grau de luminosidade no galpão de produção. Engenharia Agrícola, Jaboticabal, v.27, n.3, p.611-618, 2007.

OLESEN, B. W. Radiant floor heating: in theory and practice. ASHRAE, 2004. p. 19-26.

ROSSI, L.A.; CARDOSO, E.R.; BERALDO, A.L. Desenvolvimento e construção de placas de argamassa de cimento e casca de arroz aquecidas por resistência elétrica. Revista de Ciências Exatas e Tecnologia, Piracicaba, v. 11, n. 1, 2002.

SANTOS, T. M. B.; JÚNIOR, J. L. Balanço energético em galpão de frangos de corte. Engenharia Agrícola, Jaboticabal, v.24, n.1, p. 25-36, 2004.

TINÔCO, I. F. F. Avicultura Industrial: novos conceitos de materiais, concepções e técnicas construtivas disponíveis para galpões avícolas Brasileiros. Revista Brasileira de Avicultura, Campinas, v. 3, n. 1, p. 1-26, jan. 2001. 
UBA - União Brasileira de Avicultura. Relatório anual 2010/2011. Brasília, DF. p.13.

VIGODERIS, R.B.; CORDEIRO, M. B.; TINÔCO, I. F. F.; MENEGALI, I.; SOUZA JÚNIOR, J. P. S.; HOLANDA, M. C. R. H. Avaliação do uso de ventilação mínima em galpões avícolas e de sua influência no desempenho de aves de corte no período de inverno. Revista Brasileira de Zootecnia, Viçosa-MG, v.39, n.6, jun. 2010.

WICKLEN G.L.; CZARICK M. Design of a PVC pipe system for brooding chickens. Transaction of the ASAE, St. Joseph, v.31, p. 552-557, 1998. 